\title{
INFLUENCE OF TIME AND HEAT TREATMENT TEMPERATURE ON PERMEABILITY OF Eucalyptus grandis WOOD ${ }^{1}$
}

\author{
Fabiana Paiva de Freitas ${ }^{2 *}{ }^{0}$, Ana Márcia Macedo Ladeira Carvalho ${ }^{3}$, Angélica de Cássia Oliveira \\ Carneiro $^{3} \odot$, Benedito Rocha Vital ${ }^{3} \odot$ Lira Maria Sivieiro Gonçalves $^{4} \odot$, Márcia Silva de Jesus ${ }^{4} \odot$ and $^{\circ}$ \\ Mariana Fonseca Xisto ${ }^{5}$ (1)
}

\footnotetext{
${ }^{1}$ Received on 10.06.2016 accepted for publication on 15.09.2017.

${ }^{2}$ Universidade Federal de Viçosa, Laboratório de paineis e energia da madeira, Viçosa,Minas Gerais - Brasil . E-mail: $<$ fabianapf@hotmail.com>.

${ }^{3}$ Universidade Federal de Viçosa, Departamento de Engenharia Florestal, Viçosa, Minas Gerais - Brasil . E-mail: <ana.marcia@ufv.br>,<cassiacarneiro1@gmail.com>and < benedito.vital@gmail.com>.

${ }^{4}$ Universidade Federal de Viçosa, Programa de Pós-Graduação em Ciência Florestal, Viçosa, Minas Gerais - Brasil. E-mail: <lirasivieiro@gmail.com> and marcia@hotmail.com>.

${ }^{5}$ Universidade Federal de Viçosa, Programa de Pós-Graduação em Biologia Celular e Estrutural, Viçosa,Minas Gerais - Brasil. E-mail: <marianaxisto@hotmail.com>.

*Corresponding author.
}

\begin{abstract}
Due to the fact that raw timber has permeability characteristics unsuitable for some applications, several processing techniques have been developed, such as hydrothermal treatments and freezing, which aim to improve these properties. The objective of this study was to analyze the effects of treatment temperature and duration on the permeability of Eucalyptus grandis wood. Heartwood samples from three E. grandis trees were utilized, each with the dimensions $30 \times 8 \times 3$ (length, width, thickness). The treatments were carried out at three temperatures $\left(-20^{\circ} \mathrm{C}, 60^{\circ} \mathrm{C}\right.$, and $\left.100^{\circ} \mathrm{C}\right)$ and three exposure durations $(5,10$, and 15 hours). Treatments at $-20^{\circ} \mathrm{C}$ were conducted inside a domestic freezer, while treatments at $60^{\circ} \mathrm{C}$ and $100^{\circ} \mathrm{C}$ took place inside a Parr Reactor, while the wood being submerged in water. Extractive removal was only observed at the surface and interior of wood treated at $60^{\circ} \mathrm{C}$ and $100^{\circ} \mathrm{C}$; while all treatment conditions increased permeability with respect to control treatments.
\end{abstract}

Keywords: Freezing; Hydrothermal; Chemical composition

\section{INFLUÊNCIA DO TEMPO E DA TEMPERATURA DE TRATAMENTO TÉRMICO NA PERMEABILIDADE DA MADEIRA DE EUCALYPTUS GRANDIS}

\begin{abstract}
RESUMO-Devido ao fato de a madeira in natura possuir características de permeabilidade inadequadas para algumas aplicações, diversas técnicas de processamento foram desenvolvidas, como tratamentos hidrotérmicos e congelamento, que visam melhorar essas propriedades. O objetivo deste estudo foi analisar os efeitos do tempo e da temperatura de tratamento na permeabilidade da madeira de Eucalyptus grandis. Foram utilizados amostras da região do cerne de três árvores de E. grandis, cada uma com as dimensões $30 \times 8 \times 3$ (comprimento, largura, espessura). Os tratamentos foram realizados a três temperaturas $\left(-20,60\right.$ e $\left.100^{\circ} \mathrm{C}\right)$ e três tempos de exposição (5, 10 e 15 horas). Os tratamentos à $-20^{\circ} \mathrm{C}$ foram realizadas dentro de um freezer doméstico, enquanto os tratamentos à 60 e $100^{\circ} \mathrm{C} \mathrm{em} \mathrm{um} \mathrm{reator} \mathrm{Parr,} \mathrm{onde} \mathrm{as} \mathrm{madeiras} \mathrm{ficaram} \mathrm{submersas} \mathrm{em} \mathrm{água.}$ Foi observado a remoção dos extrativos apenas na superficie e interior de madeira tratada a 60 e $100^{\circ}$ C; enquanto a permeabilidade aumentou para todas as condições de tratamento quando comparados à testemunha.
\end{abstract}

Palavras-Chave: Congelamento, Hidrotérmico, Composição química

Revista Árvore. 2019;43(3):e430301 


\section{INTRODUCTION}

During the 1960's, the first studies into engineering timber permeability utilized thermal treatment, as well as freezing, during the drying of wood. These studies illustrated that such treatments both increased the drying rate and reduced the frequency of some timber defects. (OLIVEIRA et al., 2003).

According to Kamdem et al. (2002), the treatment of wood with water alters the physical and chemical properties of the wood; and the magnitude of these changes is dependent on several factors including: treatment temperature, treatment duration, wood chemical composition, anatomical structure of the wood and moisture content.

Zanuncio et al. (2014) demonstrated that hydrothermal treatments can be employed to degrade hemicelluloses and increase the dimensional stability of solid wood, as well as wooden paneling. Hemicelluloses adversely affect the dimensional stability of the timber by allowing the adsorption of water in the form of humidity and may cause defects in the final product. This type of treatment may also allow the removal of extractives, non-structural components of wood, and those which are soluble in organic solvents and/or water.

Hatcher and Clifford (1997) affirmed these results by illustrating that during hydrothermal treatment, water acts as a solvent as well as a catalyst. The presence of water was shown to facilitate hydrolysis and cleavage of lignocellulosic materials within the wood. These hydrolysis reactions were made evident by an observed temperature-dependent drop in $\mathrm{pH}$, indicative of organic acid formation. The presence of these organic acidsincluding acetic acid, levulinic acid, formic acid, and lactic acid - potentialize further decomposition of wood fragments. (BOBLETER, 1994; TITIRICI et al., 2007; LIBRA et al, 2011; TITIRICI et al, 2012).

Pre-vaporization of wood can cause an increase in permeability via the removal of obstructions within the wood matrix, which in turn enhance the drying process (CHEN, 1975; HARRIS et al., 1989; ALEXIOU et al., 1990; SEVERO, 2004). Consequently, vaporization treatment results in products with fewer defects and better utility.

The anatomical structure of wood can also influence its permeability. Porosity and permeability are a direct function of cellular structures, variations in the microenvironment of cell cavities, and the prevalence of obstructions within a particular sample of wood (LIMA et al., 2007).

Therefore, different treatment conditions can be employed to remove extractives and polysaccharides, such as hemicelluloses, which can be degraded into oligosaccharides and monosaccharides. Some hemicelluloses, such as cellulose and lignin, can be further removed via temperature-dependent hydrolysis (GARROTE et al., 1999).

Another type of existing treatment is the prefreezing of wood. This particular technique offers utility in the fields of conservation and art restoration. It also offers a promising application to manufacturing, where it is sometimes employed to dry wood with small dimensions (GIOVANELLAand MUNIZ, 2010). According to Illic (1999), pre-freezing timber can reduce the frequency of shrinkage and collapse during the drying process. Hamilton (s/d) demonstrated that some of the main problems with pre-freezing treatments are the possibility of material surface blemishes and internal cracks, which in turn may alter the permeability of the timber.

This study aims to assess the effects of treatment with different temperatures and durations on the permeability of E. grandis wood.

\section{MATERIALAND METHODS}

\subsection{Methodology}

The study was perform using three trees of $E$. grandis each about 15 years of age and with an average diameter at breast height (DBH, at 1.30 meters of height) of roughly $30 \mathrm{~cm}$. These trees were sourced from a stand located in the Department of Animal Science of the Federal University of Viçosa.

Of the selected trees, the first log of each tree base with five meters in length was used. From each sample, boards three centimeters thick were isolated, consisting only of the core, with the marrow and sapwood being eliminated. From these panels, specimens measuring $30 \times 8 \times 3 \mathrm{~cm}$ (length, width, thickness) were taken.

The wood was subjected to two treatment conditions: freezing, or hydrothermal treatment. During the freezing process, timber samples were stored at $-20^{\circ} \mathrm{C}$ in a domestic freezer for 5,10 , or 15 hours. Hydrothermal treatment of the wood was carried out underwater in a digester (Parr Reactor model 4555)

Revista Árvore. 2019;43(3):e430301 
equipped with a heat exchanger (Parr 4848M). In this reactor, the wood samples were subjected to temperatures of either $60^{\circ} \mathrm{C}$ or $100^{\circ} \mathrm{C}$ with a treatment duration of 5,10 , or 15 hours.

In each treatment, six test specimens were used, presenting an initial moisture content of approximately $74 \%$. Upon completion of the treatment, specimens were removed from the freezer or Parr reactor. Subsequently, the specimens were kept at ambient temperature for 7 days. After this period, samples were conditioned in a climatic chamber at a temperature of $23 \pm 0.5^{\circ} \mathrm{C}$ and relative humidity of $65 \pm 1.0 \%$ until a constant mass was reached, allowing for further characterization. The experimental design is shown in Table 1

\subsection{Chemical composition}

Internal and surface level chemical compositions were determined in the following manner. Samples from the external surface of each wood specimen were removed with the aid of a planer. Each sample was taken approximately $1 \mathrm{~cm}$ deep from the entire surface. The remainder of each wood specimen was then utilized as the sample for the inner layer. Samples from each treatment condition were ground, classified, and sieved, collecting the fraction that passed through a 40 mesh sieve but was retained by a 60 mesh sieve (ASTM, 1982). The determination of the moisture content of the wood was carried out according to norm TAPPI 264 om-88 (TAPPI, 2001). The extractive content of each wood sample was determined in duplicate according to the method for total extractive determination outlined in norm TAPPI 204 om-88 (TAPPI, 2001), with the exception that ethanol/toluene was used in place of ethanol/

Table 1 - Experimental design

Tabela 1 - Delineamento experimental

\begin{tabular}{ccc}
\hline Treatments & \multicolumn{2}{c}{ Conditions } \\
\cline { 2 - 3 } & Temperature $\left({ }^{\circ} \mathrm{C}\right)$ & Time $(\mathrm{h})$ \\
\hline 1 & -20 & 5 \\
1 & -20 & 10 \\
1 & -20 & 15 \\
2 & 60 & 5 \\
2 & 60 & 10 \\
2 & 60 & 15 \\
3 & 100 & 5 \\
3 & 100 & 10 \\
3 & 100 & 15 \\
Witness & 23 & -
\end{tabular}

1 - Freezing treatment at $-20^{\circ} \mathrm{C}, 2$ - Treatment in water at $60^{\circ} \mathrm{C}$, 3 - Treatment in boiling water at $100^{\circ} \mathrm{C}$, Witness - No treatment. benzene. The insoluble lignin contents were determined in duplicate by the Klason method as modified by Gomide and Demuner (1986). Soluble lignin content was determined by spectrometry, as performed in Goldschimid (1971). The total lignin content was obtained by summing the soluble and insoluble lignin values, and the holocellulose content was obtained by the sum of extractive and total lignin contents, subtracted from 100.

\subsection{Permeability}

To test the permeability of each wood specimen, the rectangular samples were turned until they reached $2 \mathrm{~cm}$ in diameter and sectioned to $5 \mathrm{~cm}$ in length. After turning and sectioning, the test bodies were radially waterproofed with paraffin to inhibit air infiltration. The ends of the test bodies were covered with adhesive tape to prevent contact with paraffin. This ensured the only areas capable of conducting free air flow were the ends. The equipment for atmospheric air permeability testing was fitted with four flowmeters connected in series on the following scales and sequence: 0.04 to 0.5 LPM (liters per minute); 0.2 to 2.5 LPM; 0.4 to 5.0 LPM; and 2.0 to 25.0 LPM. This was connected via PVC tubing to a Prismatec vacuum pump, model 131 $2 \mathrm{VC}$ at one end, and the samples at the other. The vacuum pressure used in the pump was $-3 \mathrm{in}$. $\mathrm{Hg}$. It is important to note that when reading from one flowmeter, the others remained closed. These flowmeters are intended to measure the flow of air passing through the test specimens. After the pump was started, it took 10 seconds to stabilize the flow and collect the flow rate data for each sample, as well as the outlet pressure indicated by the pump (TEIXEIRA, 2015).

For the determination of the gaseous permeability of wood, equation 1 below was used, following Darcy's Law:

$$
K g=\frac{Q \cdot L \cdot P i}{A \cdot \Delta P \cdot P m}
$$

where,

$\mathrm{Kg}$ : Gas permeability $\left(\mathrm{cm}^{2} \cdot \mathrm{atm}^{-1} \cdot \mathrm{s}^{-1}\right)$;

Q: volume flow of gas that traverses the specimen $\left(\mathrm{cm}^{3} \cdot \mathrm{s}^{-1}\right)$;

L: length of test piece $(\mathrm{cm})$;

Pi: input pressure, the ambient pressure (atm); Pi: atmospheric pressure

Revista Árvore. 2019;43(3):e430301 
A: cross-sectional area $\left(\mathrm{cm}^{2}\right)$;

$\Delta \mathrm{P}:$ Pressure difference (atm);

Pm: average pressure in the specimen (atm).

\subsection{Statistical Analysis}

The experiment was conducted in a completely randomized, factorial design consisting of three temperatures $\left(-20^{\circ} \mathrm{C}\right.$, $60^{\circ} \mathrm{C}$, and $\left.100^{\circ} \mathrm{C}\right)$ and three exposure durations $(5,10$, and 15 hours). The nine treatment conditions and the control each had six replicates.

Permeability levels for each condition were compared using an analysis of variance (ANOVA) test. Mean experimental sample permeabilities were compared to each other using a Tukey's test, while the mean experimental sample permeabilities were compared to the control using a Dunnett test. The significance threshold for all tests was set at 0.05 .

\section{RESULTS}

\subsection{Chemical Composition - Wood Surface}

Table 2 shows the mean values of extractive content from the superficial layer of $E$. grandis wood for each treatment. The analysis of variance indicates that the extractive content levels were influenced by heat treatment, in addition to the fact that there were interactions between treatment temperature and duration.

It is observed that higher temperature treatments more completely eliminate wood extractives. Only treatments at $-20^{\circ} \mathrm{C}$ did not differ from the control in terms of total extractive content, as determined by a Dunnett test (á $=0.05)$

Table 2 - Mean values of extractives (\%) of the surface of Eucalyptus grandis wood acoording to the treatments

Tabela 2 - Valores médios de extrativos totais (\%) da superfície da madeira de Eucalyptus grandis em função dos tratamentos

\begin{tabular}{ccccc}
\hline Temperature & \multicolumn{3}{c}{ Time (hours) } & Average \\
\cline { 2 - 4 }$\left({ }^{\circ} \mathrm{C}\right)$ & 5 & 10 & 15 & \\
\hline-20 & Aa $6.34^{\mathrm{ns}}$ & $\mathrm{Aa} 6.23^{\mathrm{ns}}$ & $\mathrm{Aa} 6.77^{\mathrm{ns}}$ & 6.44 \\
60 & $4.33 \mathrm{Ba}^{*}$ & $4.35^{*} \mathrm{Ba}$ & $4.27^{*} \mathrm{Ba}$ & 4.31 \\
100 & $3.57 \mathrm{Cab}^{*}$ & $3.24^{*} \mathrm{Cb}$ & $3.67^{*} \mathrm{Ca}$ & 3.50 \\
Average & 4.75 & 4.60 & 4.90 & \\
Witness & 6.65 & & & \\
\hline
\end{tabular}

Averages followed by the same lowercase letters between columns (times) and upper case between lines (temperatures), do not differ from each other by the Tukey test. "n.s" indicate no significant differences and "*" indicate significant differences between the means and the control by Dunnett test (all at $95 \%$ probability level).
According to Table 2, a significant difference only appears between different treatment durations with samples treated at $100^{\circ} \mathrm{C}$. However, they did not show a tendency to increase or decrease, as observed with the effect of temperature. Despite the significance, the data presented no discrepant variations $(\mathrm{cv}=2.97 \%)$.

The analysis indicated that the total lignin content of the outer layer of $E$. grandis timber was not influenced by the treatments, presenting an average value among the heat treatments and the control of $31.57 \%$ and $31.72 \%$, respectively. The ANOVA results also indicate that insoluble lignin content was not influenced by treatment, presenting treatment and control values equal to $28.80 \%$ and $28.88 \%$, respectively. Likewise, no significant difference was detected with regards to the soluble lignin content, considering treatment and control values of $2.77 \%$ and $2.84 \%$, respectively.

Table 3 contains the mean values of the surface holocellulose content of E. grandis timber for each treatment condition. The analysis of variance indicated that there was interaction between time and temperature of treatment.

It is noted that only the treatments performed at $100^{\circ} \mathrm{C}$ for 5 hours and at $60^{\circ} \mathrm{C}$ for 15 hours showed significant differences in holocellulose content when compared to the control.

\subsection{Chemical Composition - Wood interior}

Table 4 reports the mean values of the total extractive content of the internal part of the E. grandis timber for each treatment condition. The results of the ANOVA testing indicate that the extractive content was influenced

Table 3 - Mean values of holocelulose content (\%) of the surface of Eucalyptus grandis wood according to the treatments

Tabela 3 - Valores médios do teor de holoceluloses (\%) da superfície das madeiras de Eucalyptus grandis em função dos tratamentos

\begin{tabular}{ccccc}
\hline Temperature & \multicolumn{3}{c}{ Time (hours) } & Average \\
\cline { 2 - 4 }$\left({ }^{\circ} \mathrm{C}\right)$ & 5 & 10 & 15 & \\
\hline-20 & Aa $62.84^{\mathrm{ns}}$ & Aa $61.84^{\mathrm{ns}}$ & Aa $62.89^{\mathrm{ns}}$ & 62.52 \\
60 & Aa $63.20^{\mathrm{ns}}$ & Aa $64.35^{\mathrm{ns}}$ & Aa 65.21 $1^{*}$ & 64.25 \\
100 & Aa $65.56^{*}$ & Aa $63.95^{\mathrm{ns}}$ & Aa 63.23 ${ }^{\mathrm{ns}}$ & 64.24 \\
Average & $63.86^{2}$ & $63.38^{2}$ & 63.77 & \\
Witness & 61.64 & & & \\
\hline
\end{tabular}

Averages followed by the same lowercase letters between columns (times) between the lines and capital letters (temperature), do not differ by Tukey test. "n.s" indicate no significant differences between the means and the control by Dunnett test (all at $95 \%$ probability level).

Revista Árvore. 2019;43(3):e430301 
by the hydrothermal treatments, as isolated effects only occurred in the temperature treatments. These data suggest that the higher treatment temperature result in lower extractive content. The treatments did not differ from the control.

These results indicate that the total lignin levels were not affected by treatments. The mean values of the total, insoluble, and soluble lignin content found for the control and experimental groups were 31.00, $31.04,28.73,28.71,2.27$, and $2.33 \%$, respectively. The data also suggest that holocellulose content was not significantly changed between the control and the experimental groups, presenting average values of 63.68 and $63.81 \%$, respectively.

\subsection{Permeability}

The mean values of permeability for $E$. grandis wood under each treatment condition is shown in Table 5 . The analysis of variance indicated that the permeability was affected by the treatments, presenting an isolated effect of temperature and time.

It is observed that the permeability of the wood increased with increasing temperature and time of exposure. Only the treatments at $100^{\circ} \mathrm{C}$ for 15 hours differed from the control.

\section{DISCUSSION}

\subsection{Chemical composition - Woods Surface}

The data presented in Table 2 is in agreement with Hillis (1962). Most of the extractives present in wood are readily soluble in neutral organic solvents or water,

Table 4 - Mean values of the extractives content (\%) of the inner timber of Eucalyptus grandis wood according to the treatments.

Tabela 4 - Valores médios do teor de extrativos totais (\%) do interior das madeiras de Eucalyptus grandis em função dos tratamentos

\begin{tabular}{ccccc}
\hline $\begin{array}{c}\text { Temperature } \\
\left({ }^{\circ} \mathrm{C}\right)\end{array}$ & \multicolumn{3}{c}{ Time (Hours) } & Average \\
\cline { 2 - 4 } & 5 & 10 & 15 & \\
\hline-20 & $5.36^{\mathrm{ns}}$ & $5.54^{\mathrm{ns}}$ & $5.55^{\mathrm{ns}}$ & $5.48 \mathrm{~A}$ \\
60 & $5.14^{\mathrm{ns}}$ & $5.97^{\mathrm{ns}}$ & $5.11^{\mathrm{ns}}$ & $5.41 \mathrm{~A}$ \\
100 & $4.68^{\mathrm{ns}}$ & $4.70^{\mathrm{ns}}$ & $4.32^{\mathrm{ns}}$ & $4.57 \mathrm{~B}$ \\
Average & 5.06 & 5.40 & 4.99 & \\
Witness & 5.32 & & &
\end{tabular}

Averages followed by the same lowercase letters between columns (times) and upper case between lines (temperatures), do not differ from each other by the Tukey test. "n.s" indicates non-significant differences between the means and the control by the Dunnett test (all at the $95 \%$ probability level).
Table 5-Mean permeability values $\left(\mathrm{cm}^{2} \cdot\right.$ atm $\left.^{-1} \cdot \mathrm{s}^{-1}\right)$ of Eucalyptus grandis wood according to the treatments.

Tabela 5 - Valores médios da permeabilidade $\left(\mathrm{cm}^{3} / \mathrm{cm}\right.$. amt.s $)$ da madeira de Eucalyptus grandis em função dos tratamentos

\begin{tabular}{ccccc}
\hline \multirow{2}{*}{$\begin{array}{c}\text { Temperature } \\
\left({ }^{\circ} \mathrm{C}\right)\end{array}$} & \multicolumn{3}{c}{ Time (hours) } & Average \\
\cline { 2 - 4 } & 5 & 10 & 15 & \\
\hline-20 & $9.89^{\mathrm{ns}}$ & $8.44^{\mathrm{ns}}$ & $11.70^{\mathrm{ns}}$ & $10.01 \mathrm{~B}$ \\
60 & $8.82^{\mathrm{ns}}$ & $7.97^{\mathrm{ns}}$ & $10.36^{\mathrm{ns}}$ & $9.05 \mathrm{~B}$ \\
100 & $9.37^{\mathrm{ns}}$ & $15.80^{\mathrm{ns}}$ & $22.69^{*}$ & $15.96 \mathrm{~A}$ \\
Average & $9.36 \mathrm{~b}$ & $10.74 \mathrm{ab}$ & $14.92^{\mathrm{a}}$ & \\
Witness & 7.78 & & & \\
\hline
\end{tabular}

Averages followed by the same lowercase letters between columns (times) and upper case between lines (temperatures), do not differ from each other by the Tukey test. "n.s" indicates no significant differences and "*" indicate significant differences between the means and the control by Dunnett test (all at $95 \%$ probability level).

and higher temperatures better facilitate their removal. The duration of treatment, for the same temperature, has also been shown not to have a significant effect on the amount of extractives removed. Freezing treatments differed from hydrothermal treatments, likely due to the lack of hydrolysis as these samples were not submerged in water during treatment.

The term extractive refers to substances of low or medium molecular mass, which can be extracted in water or organic solvents. The water soluble constituents of the wood are mainly inorganic salts and minerals, sugars, and low molecular weight polysaccharides (MORAIS et al., 2005).

In general, there did not appear to be significant breakdown of chemical components associated with the cell wall during wood treatment, as only the removal of different types of extractives was observed. Table 2 demonstrates a temperature-dependent reduction in total extractive content, and this trend is mirrored in the observed proportional change of holocellulose levels shown in Table 3 . This trend is expected due to the fact that hollocellulose levels were defined as the difference of total extractive and total lignin content.

According to Yildiz et al. (2006), the treatment temperature accounts for a greater effect size when compared to the treatment duration, and once temperatures reach $150^{\circ} \mathrm{C}$, alterations conferred to wood physical and chemical properties become irreversible.

\subsection{Chemical Composition - Interior of the Woods}

Conforming to what was observed in Table 4, the results show a behavior similar to the surface analysis of the wood, in which the extractive content decreases 
as treatment temperature increases. This behavior is due to the hydrophilic nature of the wood matrix, which enables water-soluble components, such as extractives, to diffuse freely throughout the entire timber sample.

As mentioned previously, treatment temperatures were not severe enough to cause degradation of the structural constituents, but they proved sufficient to promote the removal of extractives, starches, and other compounds. According to Homan et al. (2000), the thermal treatment acts on the polymer-rich regions of the wood, facilitating chemical phenomena, such as recombination, substitution, chain breakage or partial elimination of the hydroxyl groups present in the hemicelluloses. This is consistent with the observed treatment-induced change in holocellulose content.

The greater degree of extractives removal observed at the surface of treated wood samples, when compared to the interior, was expected as hydrothermal treatments of timber samples are fundamentally a diffusion-limited process.

\subsection{Permeability}

The increased permeability for treatments at $-20^{\circ} \mathrm{C}$ relative to the control may explain the observations of Taiz and Zeiger (2006), who claim that freeze-treated timber has a propensity to collapse due to internal expansion brought about as internal pockets of water crystalize during the freezing process. The increased cavity volume that results would then correspond to greater timber permeability to liquids and gases.

The direct relationship observed between permeability, treatment temperature, and treatment duration is likely associated with the water-mediated removal of extractives, the solubilization of tyloses, and the potential unclogging of vascular elements found in hardwoods. As claimed by Klitzke et al., 2008, pores obstructed by tylose, gums, and other deposits impede the capillary movement of the water in the wood, prolonging the drying process.

Wood is a heterogeneous material that exhibits large variation among trees of the same species, and even within the same tree. This heterogeneity is likely the reason for the high degree of variance in the data $(\mathrm{CV}=45.04 \%)$.

The increased permeability of timber may be beneficial in the drying process as it reduces defects and accelerates the drying rate, making it more economical and improving workability for finishing and bonding.

\section{CONCLUSIONS}

Analyzing the influence of thermal treatments on the permeability of $E$. grandis wood, it can be concluded that hydrothermal treatments occurring at elevated temperatures $\left(100^{\circ} \mathrm{C}\right)$ facilitated a greater removal of extractives in both the outer layer and the inner layer of the wood. In addition, thermal treatments, both hydrothermal and freezing, increased permeability of heartwood, which otherwise demonstrate low permeability.

\section{ACKNOWLEDGMENTS}

The Minas Gerais Research Foundation (FAPEMIG), the Coordination for the Improvement of Higher Education Personnel (CAPES) and the National Council for Scientific and Technological Development (CNPq).

\section{REFERENCES}

Alexiou PN, Wilkins AP, Hartley J. Effect of presteaming on drying rate, wood anatomy and shrinkage of regrowth Eucalyptus pilularis Sm. Wood Science Technology. 1990;24:103-10.

American Society for Testing and Materials ASTM. Standard methods of evaluating properties of wood-base fiber and particles materials. Philadelphia: 1982.

Bobleter O. Hydrothermal degradation of polymers derived from plants. Progress in Polymer Science.1994;19(5):797-841.

Chafe SC. Changes in shrinkage, collapse and green volume in the wood of Eucalyptus regnans F. Muell after heating in water. Wood Science. 1992;12(6);341- 5 .

Chen PYS. The effect of steaming time and temperature on the longitudinal permeability of black walnut. Wood and Fiber Science. 1975;3:222-5.

Garrote G, Dominguez H, Parajó JC. Hydrothermal processing of lignocellulosic materials. Holz als Roh- und Werkstoff. 1999;57(3):191-202.

Giovanella R, Muniz GIB. Congelamento de madeira - avaliação preliminar de sua utilização. Floresta. 2010;40(2):311-8.

Revista Árvore. 2019;43(3):e430301 
Goldschimid O. Ultraviolet spectra. In: Sarkanen $\mathrm{KV}$, Ludwing $\mathrm{CH}$, editors. Lignins: occurrence, formation, structure and reactions. New York: John Wiley; 1971. p.241-66.

Gomide JL, Demuner BJ. Determinação do teor de lignina em material lenhoso: método Klason modificado. O Papel. 1986;47(8):36-8.

Harris RA, Shroeder JG, Addis SC. Steaming of red oak prior to kiln-drying: effects on moisture movement. Forest Products Journal. 1989;39(11/ 12):70-2.

Hamilton DL. Secagem por congelamento. In: Conservação de achados submarinos: conservação da madeira. [s.d](Apostila de Curso).

Hatcher PG, Clifford DJ. The organic geochemistry of coal: from plant materials to coal. Organic Geochemistry.1997;27:251-74.

Hillis WE. Wood extractives. New York: Academic Press;1962. p.59-4.

Illic J. Shrinkage-related degrade and its association with some physical properties in Eucalyptus regnans F. Muell. Wood Science and Technology. 1999;33(5):425-37.

Kamdem DP, Pizzi A, Jermannaud A. Durability of heat-treated wood. Holz als Roh-und Werkstoff. 2002;60:1-6.

Klitzke RJ, Savioli DL, Muñiz GIB, Batista DC. Caracterização dos lenhos de cerne, alburno e transição de jatobá (Hymenaea sp.) visando ao agrupamento para fins de secagem convencional. Scientia Forestalis. 2008;36(80):279-84.

Libra JA, Ro KS, Kammann C, Funke A, Berge ND, Neubauer Y, et al. Hydrothermal carbonization of biomass residuals: a comparative review of the chemistry, processes and applications of wet and dry pyrolysis. Biofuels. 2011;2:71-106.

Lima CKP, Mori FA, Mendes LM, Carneiro ACO. Características anatômicas e química da madeira de clones de Eucalyptus e sua influência na colagem. Cerne. 2007;13(2):123-9.
Morais SAL, Nascimento EA, Melo DC. Análise da madeira de Pinus oocarpa Parte 1 - Estudo dos constituintes macromoleculares e extrativos voláteis. Revista Árvore. 2005;29(3):461-70.

Oliveira LS, Santini EJ, Haselein CR. Efeitos de prétratamentos de água quente e Congelamento na taxa de secagem da madeira de Eucalyptus grandis Hill ex Maiden. Floresta e Ambiente. 2003;10(2):11.

Severo ETD. Pré-vaporização: uma técnica para otimizar a secagem de madeira sólida de Eucalyptus grandis [Livre Docência]. Botucatu: Universidade Estadual Paulista; 2004.

Taiz L, Zeiger E. Fisiologia vegetal. $3^{\mathrm{a}}$. ed. São Paulo: Artmed; 2006.

Technical Association of the Pulp and Paper Industry - TAPPI. TAPPI test methods T 264 om88: Preparation of wood for chemical analysis. Atlanta: 2001.

Teixeira RU. Efeito da produtividade florestal e permeabilidade da madeira de eucalipto na velocidade de secagem [dissertação]. Viçosa, MG: Universidade Federal de Viçosa; 2015.

Titirici MM, Thomas A, Yu SH, Muller JO, Antonietti M. A direct synthesis of mesoporous carbons with bicontinuous pore morphology from crude plant material by hydrothermal carbonization. Chemistry of Materials. 2007;19:4205-12.

Titirici MM, White RJ, Falco C, Sevilla M. Black perspectives for a green future: hydrothermal carbons for environment protection and energy storage. Energy Environmental Science.2012;5:6796-822.

Yildiz S, Gezer ED, Yildiz EC. Mechanical and chemical behavior of spruce wood modified by heat. Building and Environment. 2006(41):1762-6.

Zanuncio AJV, Motta JP, Silveira TAS, Trugilio PF. Physical and colorimetric changes in Eucalyptus grandis Wood after heat treatment. BioResources. 2014:9(1):293-303. 